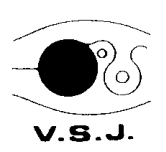

\title{
アジ化銀ペレットのレーザ起爆で 発生する衝撃波の初期形状*
}

\author{
水書 稔治 $^{1}$, ハラルド クライネ ${ }^{2}$, 片山 雅英 $^{3}$, 高山 和喜 $^{1}$ \\ Visualization of the Early Stages of Shock Waves Generated with \\ Silver-Azide Pellets by Laser Ignition Methods
}

\author{
Toshiharu Mrzukaki, Harald Kleine, Masahide Katayama and Kazuyoshi Takayama
}

\begin{abstract}
This paper describes the feature of shock waves generated by micro-charges, silver-azide, in the early stage of propagation. Silver-azide pellets (10 $\mathrm{mg}$, cylindrical shape) were ignited with pulsed laser. Direction-indicating color schlieren method, schlieren method and doubleexposure holographic interferometry were employed for visualization. Four different types of ignition method were examined to make the effects on the shock waves clear. In all the cases of ignition method, silver-azide pellets provided distorted spherical shock waves. The distorted portion on the shock waves, however, disappeared with propagation in the air. The propagation distance to transform to perfect spherical shock waves was estimated to be 120 $\mathrm{mm}$. Additional experiments with reducing the weight of silver-azide to $0.5 \mathrm{mg}$ was carried out to make it clear that a micro-charge with irregular shape would generate perfect spherical shock wave. The results from numerical simulation done with AUODYN-2D indicated that existence of directional combustion jet along the cylindrical axis was the major reason why the generated shock waves were distorted.

Keywords : Silver-azide, Micro-charges, Direction-indicating color schlieren method, Spherical shock waves, AUTODYN-2D
\end{abstract}

\section{1. 緒 論}

東北大学流体科学研究所衝撃波研究センターでは衝撃 波発生源の一つとして, 成形された微小爆薬であるアジ 化銀ペレットを利用し，特に医療応用に重点を置いた水 中衝撃波技術の確立を行ってきた ${ }^{1)}$ 。近年，アジ化銀ぺ レットを活用し, 微小爆発による大規模爆発模擬手法の 確立を目指している。これは，大規模爆発の環境影響に 関する数值シミュレーション ${ }^{2)}$ の高精度化手法の一つと して位置づけられている。この観点から, 我々はアジ化 銀ペレットの気中爆発で発生する衝撃波の特性に注目し ている。

一般に自由空間中（大気中）で爆薬を起爆して発生す る球状衝撃波の形成過程は：(1) 点火位置から発生した爆 轟波（燃焼波を伴った衝撃波）が化学反応を急激に進行

\footnotetext{
原稿受付 2002 年 4 月 24 日

正会員 東北大学流体科学研究所

東北大学大学院 工学研究科

株式会社 CRCソリューションズ
}

させながら爆薬内部を伝播し，爆轟波が爆薬と大気との 境界に達する。同時に, 高圧の反応生成気体の急速な膨 張が開始する； (2) 膨張する高圧の反応生成気体は大気に 対しピストンと同様の作用をもたらし，初期衝撃波を駆 動する；(3) 反応生成気体の膨張に関与する主たる力は爆 発時の慣性力と反応生成気体の内圧である．膨張初期に 支配的であった慣性力は膨張に伴い急速に弱まり, 以後, 内圧が支配的になる。 その後, 内圧低下と気体温度の低 下に伴い膨張はやがて停止し，ついには内側に向かって 収縮し始める。その際に内向きに進行する衝撃波が駆動 され, 中心部で収束・反射後, 外向きに伝播する二次衝 撃波となる. 反応生成ガスは膨張・収縮を繰り返しなが ら発散する；(4) 初期衝撃波及び二次衝撃波が同心球で共 に外向きに伝播するが, 距離と共に波面速度が音速に近 づき, 減衰し, ついに消失する。

上述の過程は点爆源を仮定した現象であり，ペレット として成形された微小爆薬の起爆で発生する初期衝撃波 の波面形状, 特に球状衝撃波が形成されるまでの過渡形 状については不明な点が多い, 本研究では, 初期衝撃波 
の波面形状が球形となるまでの過渡的状態を初期形状と 定義し，ペレット形状と起爆方法が初期形状に与える影 響について述べる。具体的には，アジ化銀ペレットを レーザ起爆し, 発生した衝撃波を光学的可視化法の一つ である方向指標型カラーシュリーレン法を用いて計測し， 汎用衝撃解析コードを用いた数值計算結果と比較した。

\section{2. 実験装置及び方法}

\section{1 アジ化銀ペレット}

Fig. 1 にアジ化銀ペレット（薬量 $10 \mathrm{mg}$, 円筒形状, 直径 $1.5 \mathrm{~mm}$, 長さ $1.5 \mathrm{~mm}$, アジ化銀含有率 $99.9 \%$ 以, 密度 $3.8 \mathrm{~g} / \mathrm{cm}^{3}$, 中国化薬社製，以下ペレットと呼ぶ）の 形状と底面の拡大写真を示す。ペレットにパルスレーザ 光, 特に $\mathrm{Q}$ スイッチを利用したジャイアントパルス光を 照射すると有意に検出できない時間差 $(1 \mu \mathrm{s}$ 未満 $)$ で起 爆し, また, 起爆に要するエネルギーは約 $4 \mathrm{~mJ} / \mathrm{cm}^{2}$ で ある.このことは筆者らの研究によって確認されてい $ろ^{3)}$.

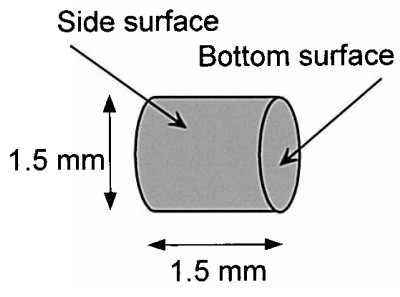

(a) $\mathrm{AgN}_{3}$ pellet shape

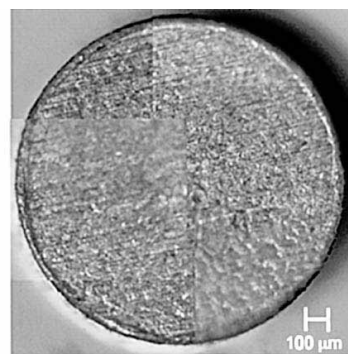

(b) Microscopic picture of bottom surface
Fig. 1 Silver-azide pellet.

\section{2 起爆方法}

レーザ光をペレットに照射する方法として：(1)ペレッ 卜を直径 $0.9 \mathrm{~mm}$ （被覆を含む）の光ファイバの一端に固

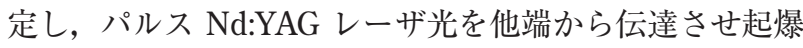
する方法（光ファイバ法と呼ぶ）；(2)ペレットにパルス $\mathrm{Nd}$ :YAG レーザ光を直接照射して起爆する方法（直接照 射法と呼ぶ）の 2 方法を試みた。

\subsection{1 光ファイバ法}

Fig. 2 (a) に光ファイバ法の実験系を示す. 光源はパ ルス Nd:YAG レーザ（波長 $1064 \mathrm{~nm}$, 出力 $14.1 \pm 0.1 \mathrm{~mJ}$, パルス幅 $9.1 \pm 0.2 \mathrm{~ns}$, 光束径約 $3 \mathrm{~mm}$, Laser Photonics 社製）を用いた。光ファイバはゲルマニウム添加石英コ アファイバ（クラッド径 $0.5 \mathrm{~mm}$ ，コア径 $0.4 \mathrm{~mm}$ ，フジ クラ社製 GC-400/500）である. 光ファイバの先端を表面 荒さ\#2000 の紙ヤスリで磨き，そこにペレットをアル ファ・シアノアクリレートが主成分である接着剤で固定 した.

光ファイバのレーザ側の端面ではレーザ光束径が光 ファイバのコア径より大きく，実際に光ファイバに入力 するレーザエネルギーは，レーザ光束径と光ファイバ径

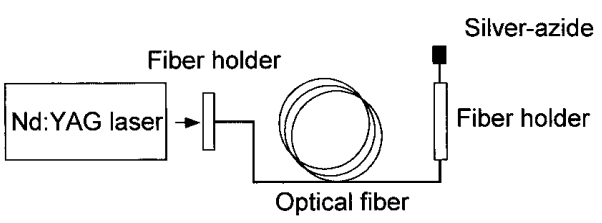

(a) Optical fiber method

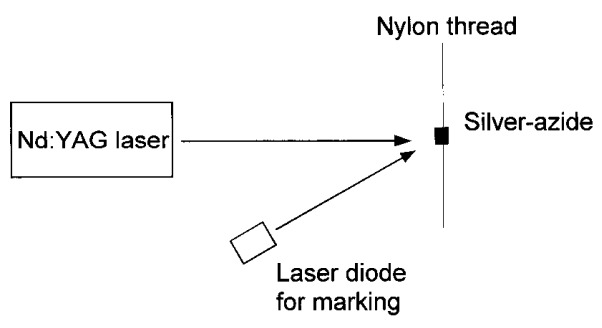

(b) Direct irradiation method

Fig. 2 Laser ignition methods.

の面積比から推定すると，レーザ光全エネルギーの約 $1 / 50$ 程度となる。したがって，0.31 mJ 程度のレーザエ ネルギーが光ファイバ内を伝播後，アジ化銀表面に到達 することとなる．ここで光ファイバ中での減衰は無視す る．到達するエネルギーは単位面積あたりに直すと 25 $\mathrm{J} / \mathrm{cm}^{2}$ 程度となりアジ化銀の起爆に十分な值である.さ らに, 薬量 $10 \mathrm{mg}$ のアジ化銀が完爆した際に発生する全 エネルギーは $18 \mathrm{~J}$ 程度（アジ化銀の TNT 換算係数を 40\% TNT としている，TNT のエネルギーは $4610 \mathrm{~J} / \mathrm{g}$ ) となり, 起爆のために入力するレーザエネルギーはアジ 化銀が爆発して発生するエネルギーの 1/60000 程度であ るため, 衝撃波の生成は, ペレットの爆発エネルギーの 寄与のみを仮定する。

\section{2.2 直接照射法}

Fig. 2 (b) に直接照射法の実験系を示す. 光ファイバ 法と同じ光源を用いる。ペレットを直径約 $0.1 \mathrm{~mm}$ のナ イロン糸にアルファ・シアノアクリレートを主成分とす る接着剤で固定する。スレッドホルダ（固定用治具）に ナイロン糸の両端を緊張させて固定し, ペレットを空中 に保持する。 Nd:YAG レーザ光を正確にアジ化銀に照射 するために感熱紙と半導体レーザ（波長 $670 \mathrm{~nm}$, 出力

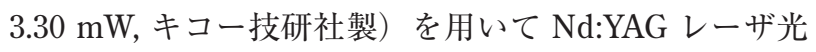
の光路をあらかじめ同定した。これらの準備で比較的容 易にかつ正確に Nd:YAG レーザ光の光路上にペレットを 固定することができる，直接照射法ではアジ化銀が受光 するエネルギーは，底面（直径 $1.5 \mathrm{~mm}$ ）に垂直に照射し た場合, $\mathrm{Nd}: Y A G$ レーザの光束径との比から約 $3.5 \mathrm{~mJ}$ と 推測できる. 実際には Nd:YAG レーザビームの光強度分 布は断面上で均一ではない. 均一であると仮定すると直 接照射の場合には起爆のために使われるエネルギーは完 爆したアジ化銀が発する総エネルギーの $1 / 5000$ 程度とな り，光ファイバ法と同様に，発生する衝撃波に有意な影 響を与えるとは考えない。 


\section{3 光学的可視化}

衝撃波の可視化計測には方向指標型カラーシュリーレ ン法 ${ }^{4)}$ - 7) (Direction-indicating color schlieren method, 以下 DICS と呼ぶ）を用いた。 Fig. 3 にその光学系を示 す.

DICS は従来のシュリーレン法を改良・発展させた手 法であり，様々な特長を持つ。シュリーレン法と呼ばれ ている従来の手法の多くは画像記録用フィルム側の焦点 位置にナイフエッジを置き，記録面上でナイフエッジに 直交する方向の密度勾配を画像の濃淡で表す．また，カ ラーシュリーレン法と呼ばれているものの多くは，密度 勾配の正負を 2 種類の色（例えば赤と青）で着色して表 すものである ${ }^{8)}$. しかし，これらの手法（従来法と呼ぶ） には改良すべき点も多い.

すなわち，従来法では：

・スリットやピンホールを導入することで光源の像を小 さくし画像の分解能を高めようとすると，回折で視野 が暗くなり画像の質の劣化を招く;

・一対の凹面鏡を用い $Z$ 型配置を採用すると，非点収差 を生じ結像位置がサジタル像点（球欠的像点）及びメ リジオナル像点（子午的像点）の 2 箇所に現れるので, 同時にこの二結像点をナイフエッジで遮断できない. その結果, 厳密に言えば 2 次元現象の計測はできない, などの実際上の不備がある。これに対し DICS は：

・光源側に光源の光をカラーソースマスクで多色（例え ば，赤，緑，青など）に色分解し，フィルム側に単純 なカットオフ機構を置いて回折効果による画像の質の

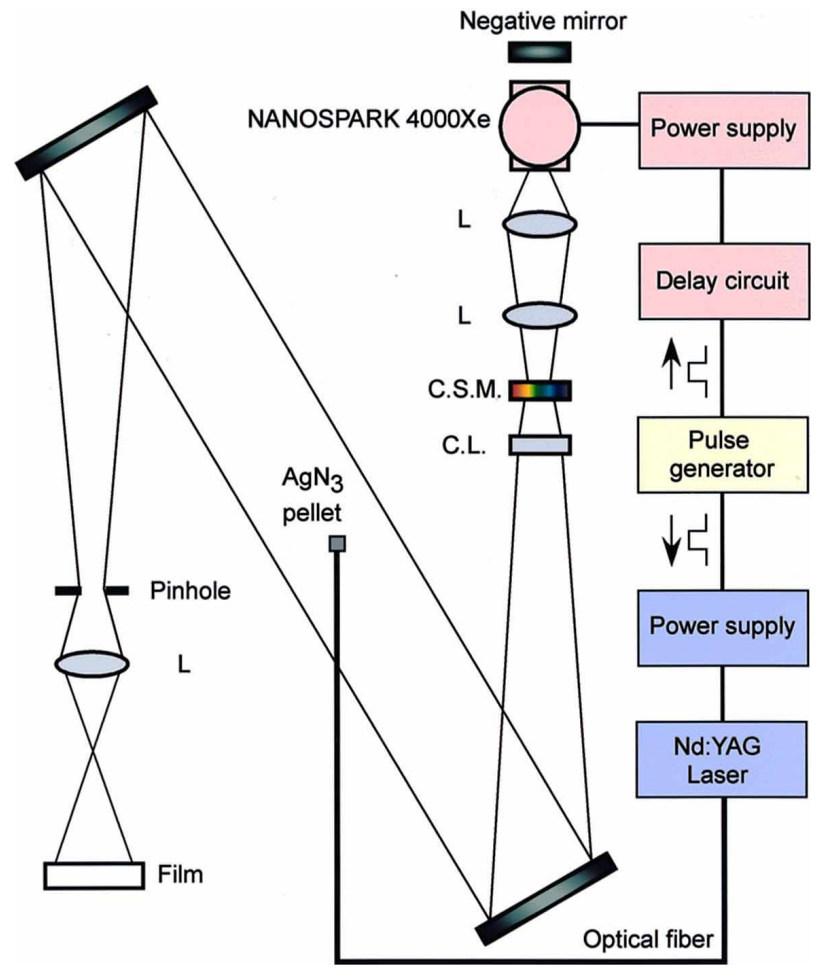

Fig. 3 Schematic diagram of direction indicating color schlieren method.; C.M.: Concave mirror, L.: Lens, C.S.M.: Color source mask, C.L.: Cylindrical lens.
劣化を防ぐ；

・カラーソースマスクの前にすりガラスを配置し色分解 された光を完全に混合させて凹面鏡に導き, 測定部を透 過する光を平行白色光線にする;

- 凹面鏡の Z 型配置にあらわれる非点収差で生じる結像 位置のずれを円筒レンズで補正して一点に結像させて, 2 次元現象の可視化を容易にする,

などの特長がある。 その反面，DICS の欠点は：

・光源側にすりガラスを置いて多色光を拡散・混合する ので，光量の損失が顕著になり従来の方法と比較する と強力な光源が必要である.

・また，衝撃波などの高速の非定常現象を可視化すると き, 発光時間の非常に短い白色光源が必要となる.

光源として高輝度短パルススパーク白色光源 ${ }^{9}$ ) (発光

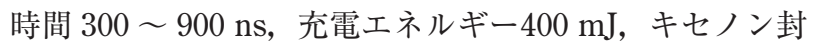
入，横浜技術研究所製ナノスパーク NS-4000P）を用いた. カラーソースマスクの一例を Fig. 4 に示す。台紙を切 り抜き，それぞれの色ゼラチンフィル夕 (Kodak 社製ゼ ラチンフィル夕, 赤: No. 29, 緑: No. 61, 青 : No. 47B) を張り合わせた。結像側でカラーソースマスク像を真円 とするため，後述する円筒レンズによる像のゆがみを考 慮しているため光が透過する領域が外楕円と内楕円に挟 まれた扁平ドーナッ形状としている，ただし，カラー ソースマスクの内楕円は正しくは楕円ではない。 三色の うち，記録画像の背景色とする色フィルタがやや内楕円 内に侵入するように変形楕円としている.

透過した光は，カラーソースマスク直後に密着させた 拡散板（フロスト型拡散板, 砂番 \#1500, 直径 $30 \mathrm{~mm}$, 厚さ $2 \mathrm{~mm}$, シグマ光機製) により, 各光線の進行方向 がランダムな状態となる。拡散光の一部が円筒レンズを 通過し，さらに凹面鏡（第 1 シュリーレン鏡：直径 300 $\mathrm{mm}$, 焦点距離 $1500 \mathrm{~mm}$ ）を見込む角度内に散乱した光 線が凹面鏡で反射し平行光束となる。ここで，円筒レン ズは，凹面鏡による非点収差を補正するために設置し， 光束の拡散角のうち垂直方向成分のみを補正する。測定 部を通過する平行光束は，従来法と同様の振る舞いをす る.すなわち, 現象が発生している際には, 局所的な密 度変化を経験し, 相応の屈折角に偏向され再び凹面鏡 （第 2 シュリーレン鏡）により集光される，カラーソース

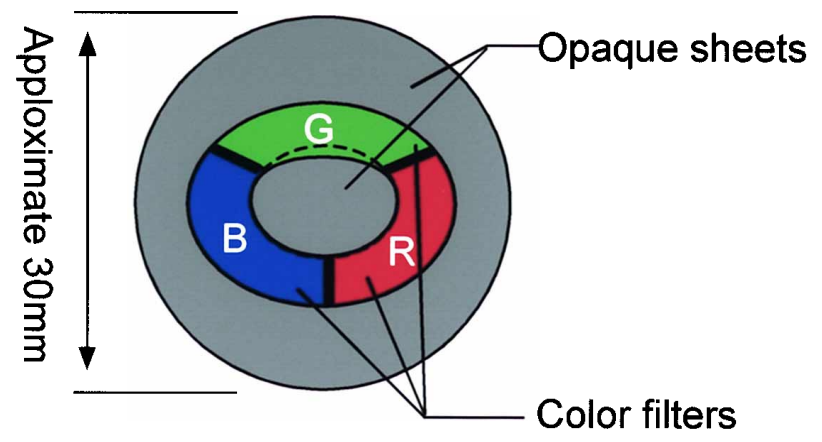

Fig. 4 Color-source mask; R: Red, G: Green, B: Blue. 
マスク像が結像される位置にピンホール（虹彩絞り：最 大開口径 $30 \mathrm{~mm}$ ，最小開口径 $1 \mathrm{~mm}$ ，シグマ光機社製） を設置する。ピンホールの開口径をカラーソースマスク の内円直径と等しくすることで，カラーソースマスクの カラーフィルターを透過し，かつ測定部での偏角なしの 光線を遮断する。このことによりピンホールを通過でき る光線は, 次の二種類のみとなる。すなわち，1つは背景 光として設定された光線，他方は現象により偏角を与え られた光線である。これらの光線は，結像レンズを経て 記録面（ISO400，35 mm リバーサルフィルム，富士写真 フィルム社製 Provia400）で測定部像を結像し，密度変化 が発生した部位を着色する。また，測定部に現象が発生 しない場合には，記録画像は背景色のみのモノクロ画像 となる，着色の様態で，記録画像上での密度勾配べクト ル（2 次元）が表現されるが，その様態はカラーソース マスクの配色の組み合わせに依存するため，カラーソー スマスクごとに基準画像が必要となる，我々は，画像の 色と密度勾配の方向を対応させるために，撮影の度に長 焦点凸レンズ（直径 $30 \mathrm{~mm}$ ，焦点距離 $10 \mathrm{~m}$ ）を測定部に 設置し，参照画像を撮影する．Fig. 5 に長焦点凸レンズ を撮影した参照画像の概略を示す。凸レンズの中心部は 外縁に比して厚いので，レンズの中心付近を透過する光 は，外縁を透過する光線より大きな密度変化を受ける。

したがって，像面の密度勾配べクトルは各外縁から中心 方向にとなる，外縁から中心に向かうベクトルの全集合 は平面上のすべての位置べクトルに対応する，したがっ て, 参照画像から注目領域の密度勾配ベクトルの判定が 可能となる.

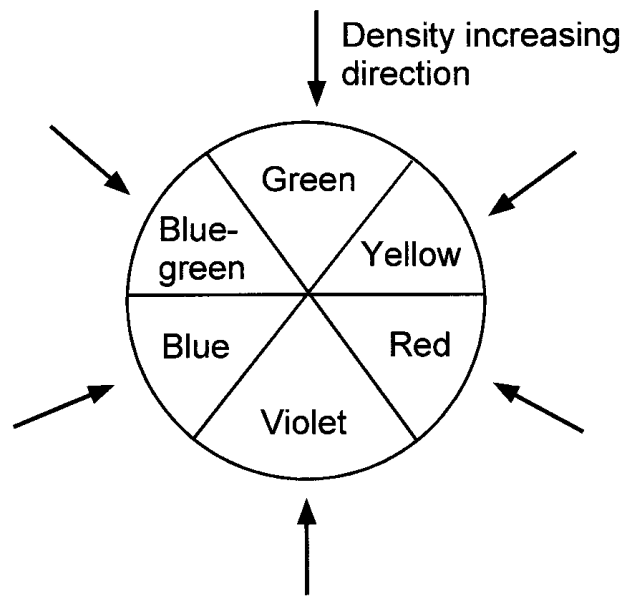

Fig. 5 Reference image.

\section{4 撮影方法}

Fig. 6 に測定に関するパラメタを，Table 1 に測定した ものの一覧を示す，測定パラメタは，起爆方法，レーザ 照射位置及び可視化方向とし，各 2 通りとした。した がって，8種類の測定条件が可能であるが，物理現象の 類似性を考慮し，有意なもののとして Fig. 6 に示す 4 通 りを選択した。

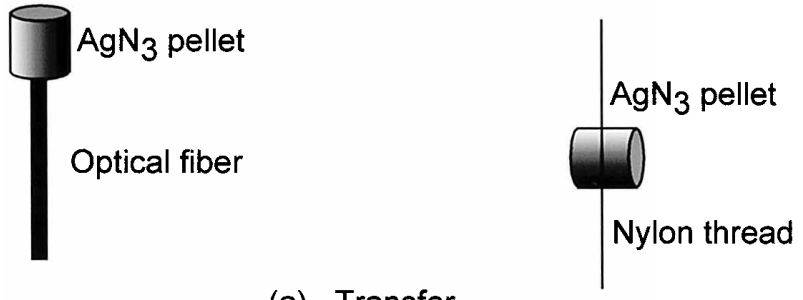

(a) Transfer

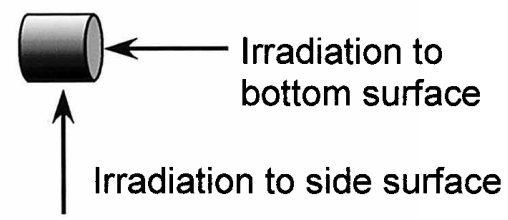

(b) Irradiated surface

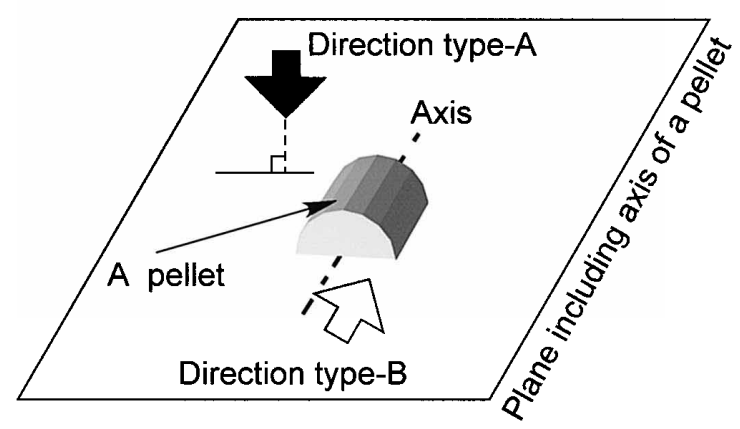

(c) Observation surface

Fig. 6 Experimental parameter; (a) Transfer media, (b) Irradiated surfaces, (c) Observation directions.

Table 1 Experimental parameters; O.F.: Optical fiber, D.I.: Direct irradiation.

\begin{tabular}{|c|c|c|c|}
\hline & (a) & (b) & (c) \\
\hline Case 1 & O.F. & Bottom & A \\
\hline Case 2 & O.F. & Side & A \\
\hline Case 3 & D.I. & Side & A \\
\hline Case 4 & D.I. & Side & B \\
\hline
\end{tabular}

\section{3. 結 果}

可視化結果を Fig. 7 に示す. Fig. 7 (a), (c), (e) 及 び（g）が可視化画像, Fig. 7 (b)，(d)，(f) 及び (h) が それぞれの起爆方法の模式図である。

すべての条件で初期衝撃波（I.S.）及び 2 次衝撃波 （S.S.）が明確に可視化された. 可視化の瞬間は, 起爆後 $180 \mu \mathrm{s}$ である。

Fig. 7 (a)，（c) 及び (e) において I.S. 及び S.S. は歪ん だ球である. Fig. 7 (d) では I.S. 及び S.S.の歪みが確認 されなかった。初期衝撃波に歪みが発生する理由を次の ように考える. 起爆後のペレット内では約 $6 \mathrm{~km} / \mathrm{s}$ の爆 轟速度で化学反応が進行する。したがって爆轟波は, 長 さ $1.5 \mathrm{~mm}$ のペレット中を約 $250 \mathrm{~ns}$ で反対側の端面まで 


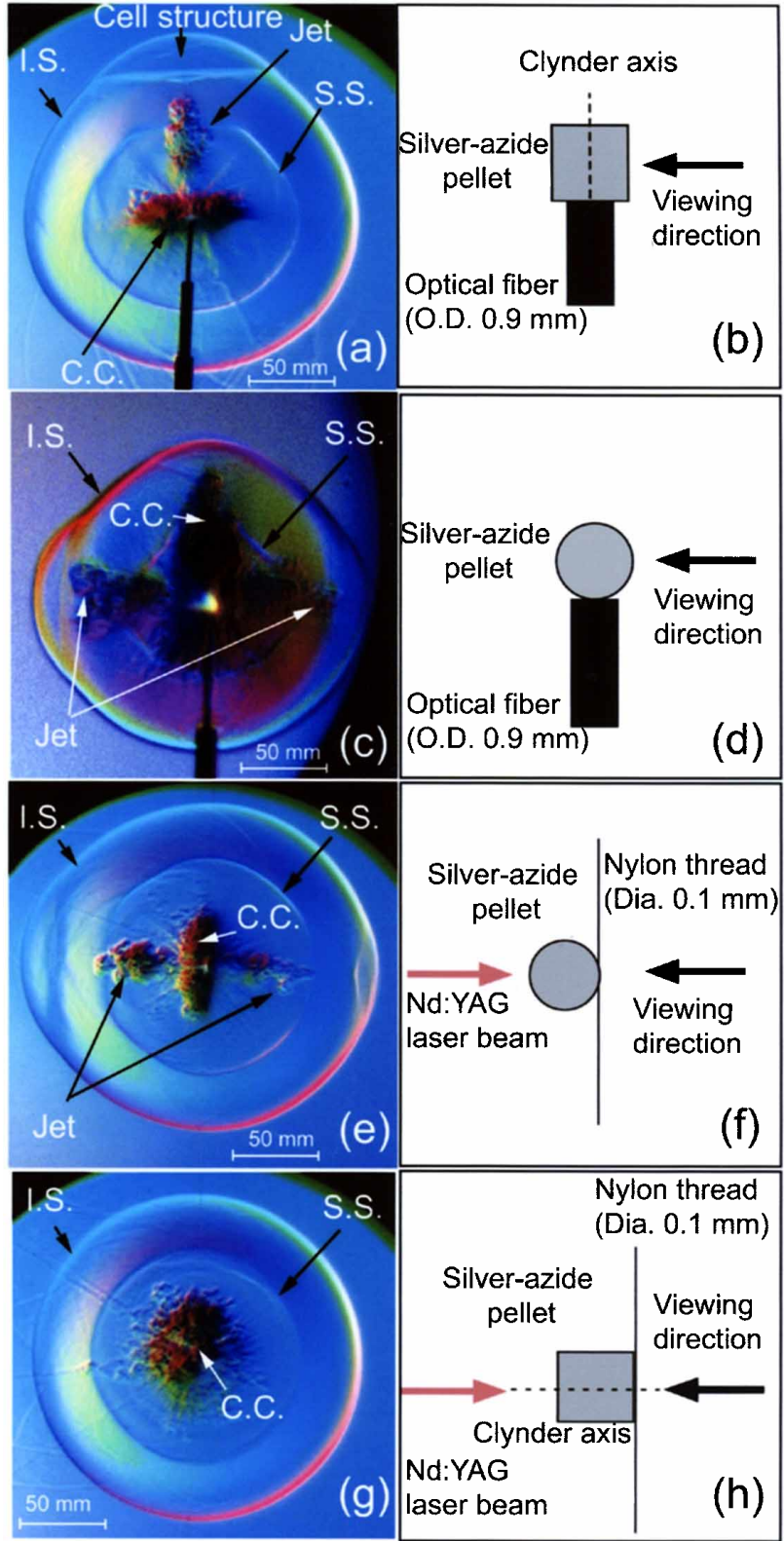

Fig. 7 Visualized shock waves generated by $10 \mathrm{mg}$ silver-azide pellets; $180 \mu$ s after ignition, I.S.: Incident shock waves, S.S.: Secondary shock waves, C.C.: Combustion Cloud.

伝播し，空気中に強い衝撃波となって解放される。この 衝撃波背後には瞬間的に爆轟波の伝播方向に強い指向性 を持つ高速気流（反応生成気体噴流，Jet）が誘起される。 爆発的に膨張する反応生成気体が衝撃波を駆動する。爆 轟波の伝播方向に駆動された衝撃波とそれ以外の方向に 駆動された衝撃波との組み合わせで，歪んだ I.S. 及び歪 んだ S.S. が形成された。ただし，Fig. 7 (d) はペレット の軸方向からの可視化した画像であるため, Jet は視野に 垂直方向にあり，衝撃波の歪みは明瞭に可視化されな かった。

爆発中心付近の暗部は，反応生成気体（C.C.）であり， このうち，特に指向性の強い流れが Jetである。C.C.の 密度は周囲の気体の密度に比して高いので通過する平行 光線が受ける偏角が大きくなり，偏角を受けた光線の大
部分がカラーソースマスクの遮光部に阻まれ，暗い画像 となる，そのため，内部の詳細は確認できなかった。そ れぞれの起爆方法ごとに C.C. は不規則な形状で現れ，円 筒形状の底面で起爆したときと側面で起爆した場合では 異なる．起爆法ごとに形状が異なる原因については後述 の考察で検討する.

起爆後 $220 \mu \mathrm{s}$ 後, I.S. の伝播距離が約 $120 \mathrm{~mm}$ の状態 を Fig. 8 に示す. 起爆方法と可視化方向は Fig. 7 (e) と 同等である.Jetによる干渉が若干残るものの，I.S. 及び S.S. は真球に漸近している.さらに，起爆後 $500 \mu \mathrm{s}$ 後, I.S.の伝播距離が約 $230 \mathrm{~mm}$ の状態を，二重露光ホログ ラフィ干渉計で可視化した結果を Fig. 9 に示す. I.S. 及 び S.S.（点線円部分）が球状であることが確認できる. 背景の不規則な縞は室内大気の対流が可視化されたもの であり，アジ化銀の爆発とは無関係である。起爆方法と 可視化方向はFig. 7 (c) と同等である. 光源は波長 $694.3 \mathrm{~nm}$ ，エネルギー3 J，パルス幅 $20 \mathrm{~ns}$ の Q-switched ルビーレーザ（INNOLAS 社製 HLSR20）である。直径 1029 mm (42 in.), 曲率半径 $16 \mathrm{~m}$ の凹面鏡を光学系に 用いた. このため, 光学系の平行光部の光路長が $16 \mathrm{~m}$ となり，一般的な二重露光ホログラフィ干渉計と比較し 数倍から十倍以上大きなものとなった。

このように爆心の近傍での初期衝撃波には歪みが伴う が，伝播と共に球状衝撃波に移行し，爆心から $120 \mathrm{~mm}$ 程度の伝播後，ほぼ完全な球状衝撃波となる。

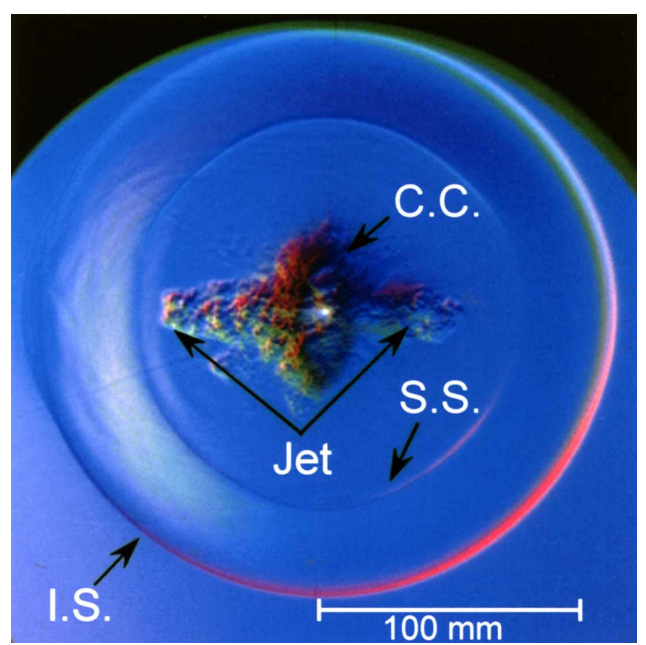

Fig. 8 Visualized shock waves generated by $10 \mathrm{mg}$ silver-azide pellets; $220 \mu$ s after ignition, I.S.: Incident shock waves, S.S.: Secondary shock waves, C.C.: Combustion Cloud.

\section{4. 考察}

ペレットを起爆して得た衝撃波の初期形状は球ではな く，反応生成気体噴流（Jet）の影響で局所的に歪んだも のであった。Jet 発生の様態には, 爆薬の形状やペレット 内での爆轟波の伝播の仕方が強く影響を与えると仮定し, 初期衝撃波に対するJetの干渉を次のように考察した。 


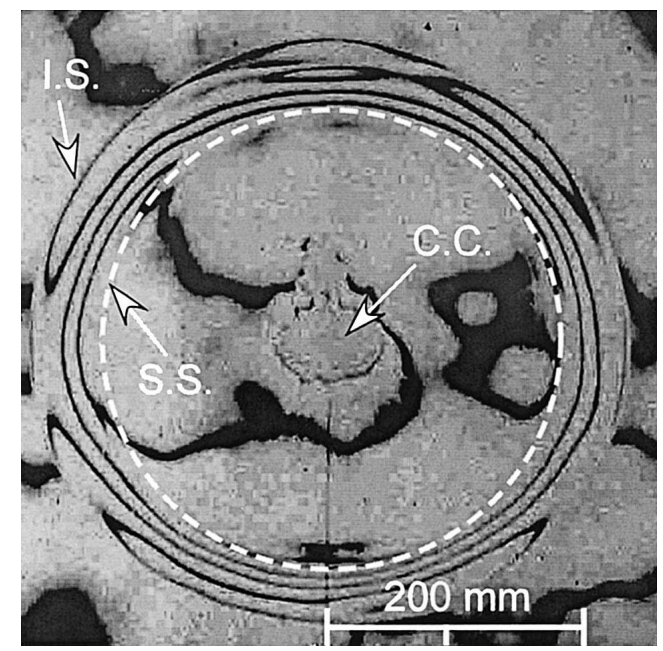

Fig. 9 Visualized shock waves generated by $10 \mathrm{mg}$ silver-azide pellets by double exposure holographic interferometry; $500 \mu$ s after ignition, I.S.: Incident shock waves, S.S.: Secondary shock waves, C.C.: Combustion Cloud.

\section{1 実験的検証}

ペレットを細かく砕き，適当な大きさの破片を選んで $500 \mu \mathrm{g}$ に調整したものを起爆させ，発生した初期衝撃波 をシュリーレン法で連続的に可視化した。

$500 \mu \mathrm{g}$ 砕片の拡大写真を Fig. 10 に示す.シュリーレ ン光学系の画像記録装置として高速フレーミングカメラ (IMACON468, Hadland Photonics Ltd.) を用いた。カ メラの受像面は CCD $(576 \times 385$ ピクセル) であり濃淡 諧調の画像が記録される，起爆法は直接起爆法である。

Fig. 11 に可視化結果を示す。初期衝撃波（I.S.）及び 二次衝撃波（S.S.）に歪みは確認されなかった。撮影は起 爆後 $24.6 \mu \mathrm{s}$ から $50 \mu \mathrm{s}$ ごとに $274.6 \mu \mathrm{s}$ まで行った。露 出時間はそれぞれ $200 \mathrm{~ns}$ である. Fig. 11 (d) が，Fig. 7 で示したペレット爆発の可視化測定瞬間とほほ同等のも のである. Fig. 11 からわかるように測定した時間範囲内 では Jetによる I.S. 及びS.S.への干渉はなく，ほほ完全 な球状衝撃波を確認した。この現象は再現性がよいこと も確認した。

$500 \mu \mathrm{g}$ 砕片の爆発で初期衝撃波の歪みが発生しない理

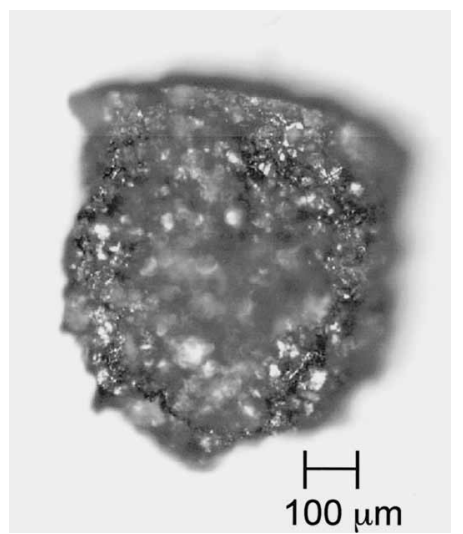

Fig. $10500 \mu \mathrm{g}$ silver-azide fragment.

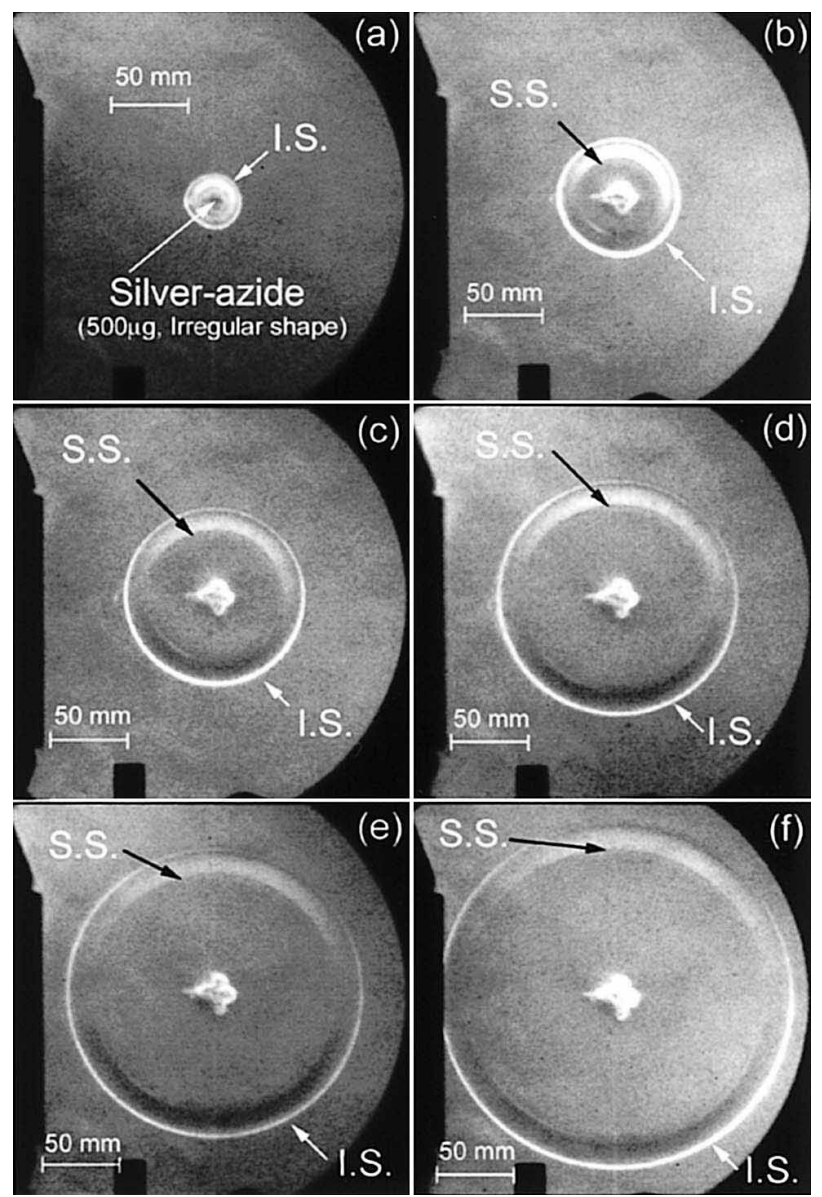

Fig. 11 Visualized shock waves generated by a $500 \mu \mathrm{g}$ silverazide fragment; I.S.: Incident shock waves, S.S.: Secondary shock waves.

由は爆薬が微小で不規則形状をしているためである。す なわち，砕片全体に爆轟波が伝播するために要する時間 がペレットと比較して小さく，最大で $100 \mathrm{~ns}$ 程度である こと，また，不定形をしていることもあり，Jet が局所的 に強く誘起されることがない。ただし，微量の爆薬であ るため解放されるエネルギーも微小であり（約 $1 \mathrm{~J}$ ), 衝 撃波は直ちに減衰する傾向を示した。

\section{2 数值解析}

Fig. 7 (a) 及び (c) に対応した数值解析を爆発衝撃問 題の解析で実績のある商用コードの AUTODYN-2D ${ }^{10), 11}$ を用いて行い，実験結果と比較した。

\subsection{1 数值計算方法}

2 次元非定常軸対称流れ場でのペレット起爆を仮定す る。流体の粘性及び熱伝導はないものとし，基礎方程式 にはオイラー方程式を用いる。 反応生成気体の状態方程 式は(1)式に示す Jones-Wilkins-Lee（JWL）状態方程式 である。

$P=A\left(1-\frac{\omega}{R_{1} \eta}\right) \exp \left(-R_{1} \eta\right)+B\left(1-\frac{\omega}{R_{2} \eta}\right) \exp \left(-R_{2} \eta\right)+\frac{\omega \rho_{0} e}{\eta}$

ここに, $P, \rho, e, \eta$ はそれぞれ反応生成気体の圧力, 
密度, 単位質量あたりの内部エネルギー, 圧縮比 $\rho_{0} / \rho$ を表す。また， $\rho_{0}$ はアジ化銀の初期密度を表す。さらに， $\mathrm{JWL}$ パラメータと呼ばれる $A, B, R_{1}, R_{2}, \omega$ はシリン ダー膨張試験 ${ }^{12)}$ と呼ばれる爆薬の特性実験の結果から導 かれた経験的な定数で, 数表に与えられている.アジ化 銀の JWL パラメータと爆轟特性值を Table 2 に示す.

Table 2 中の $D, P_{C J}, E_{0}$ はそれぞれアジ化銀の爆速, C-J (Chapman-Jouguet) 圧 ${ }^{12)}$, 単位体積あたりの爆薬の爆発 エネルギーである。

Table 2 The specification of silver-azide.

\begin{tabular}{|c|c|c|c|c|}
\hline$A(\mathrm{kPa})$ & $B(\mathrm{kPa})$ & $R_{1}$ & $R_{2}$ & $\omega$ \\
$4.260 \times 10^{9}$ & $2.149 \times 10^{7}$ & 7.032 & 1.528 & 0.277 \\
\hline$D(\mathrm{~m} / \mathrm{s})$ & $P_{C J}(\mathrm{GPa})$ & $E_{0}\left(\mathrm{~J} / \mathrm{m}^{3}\right)$ & $\rho_{0}\left(\mathrm{~kg} / \mathrm{m}^{3}\right)$ & \\
5526 & 22.6 & $7.34 \times 10^{9}$ & 3800 & \\
\hline
\end{tabular}

JWL 状態方程式を用いた AUTODYN-2D による計算で は，反応生成気体の膨張がかなり進んだ状態で，密度が 初期值と比へ極めて希薄になる領域の発生, 内部エネル ギーの值の上昇，などの不安定が発生する。これを回避 するために, AUTODYN-2D のマニュアルに推奨されて いる方法にしたがって, 反応生成気体が爆薬の初期体積 の 100 倍程度に膨張した以降の状態方程式を JWL 状態方 程式から理想気体の状態方程式に切り替えた。初期圧に 対して極端に小さい圧力になった場合，式(1)に示した JWL 状態方程式の第 1 項及び第 2 項の指数関数部分はほ とんど無視できる。すなわち，圧力は第 3 項の寄与に よってのみ決まる。したがって，アジ化銀の反応生成気 体には固体銀などの微粒子が含まれており, 理想気体と して扱うことは厳密には不適当であることは理解の上で, 第 3 項は式変形によって理想気体の状態方程式に帰着す ることが出来るため，JWL 状態方程式を理想気体の状態 方程式へ切り替えることは妥当と判断した。.また，爆薬 を取り囲む周囲の空気は比熱比 1.4, 初期圧 $101.3 \mathrm{kPa}$, 初期密度 $1.225 \mathrm{~kg} / \mathrm{m}^{3}$ の理想気体として取り扱った。

\subsection{2 底面起爆}

底面を起爆面とした数值解析結果と可視化画像を Fig. 12 に示す.上半面は等密度線 1 本あたり $0.05 \mathrm{~g} / \mathrm{cm}^{3}$ とし た数值解析結果, 下半面は可視化画像である. 可視化の 瞬間は起爆後 $180 \mu \mathrm{s}$ であり, 数值解析結果も同時刻のも のである. 数值解析結果と可視化画像はよく一致した。

数值解析結果から, 衝撃波内部での特徴的な現象は次 の通りである。 反応生成気体 (C.C.) は膨張しつつぺ レット軸を中心に渦環（図中の点線円 A, B，C）を伴っ ている。渦環は，爆轟波がペレット内部を左端から右端 に伝播することによって発生したものである。ペレット 内部での爆轟波の伝播方向（左から右方向）に発生した 反応生成気体 (Jet) が初期衝撃波（I.S.）及び二次衝撃波 (S.S.) と干渉し，ペレット軸延長線上，特に画像右方に セル構造（C.S.）が発生している.

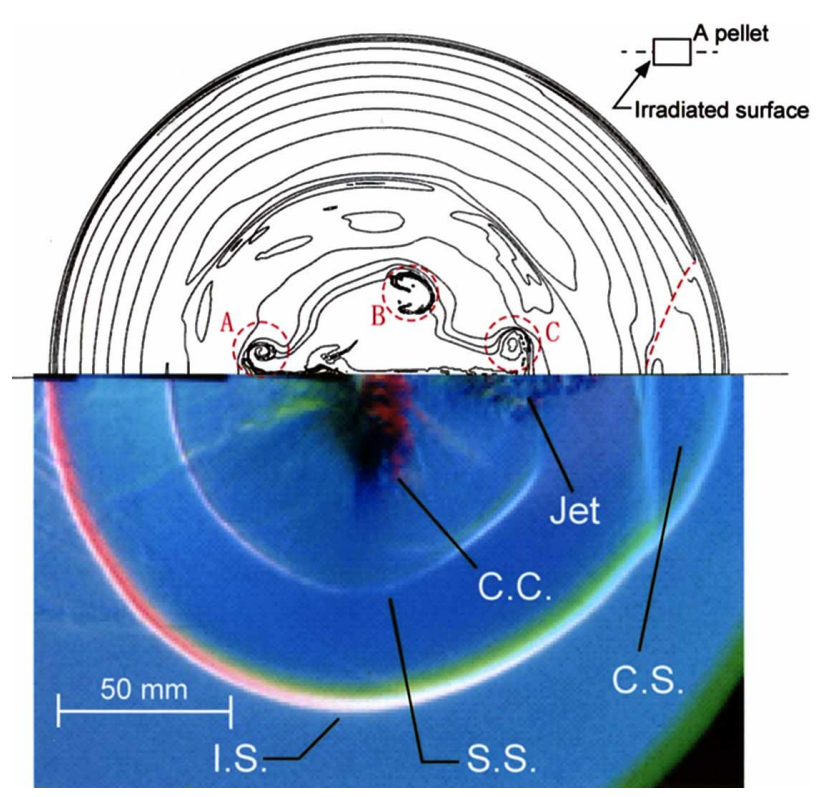

Fig. 12 Numerical results of bottom-surface ignition at $180 \mu \mathrm{s}$ after ignition, I.S.: Incident shock waves, S.S.: Secondary shock waves, C.C.: Combustion Cloud, C.S.: Cell structure.

\subsection{3 側面起爆}

側面を起爆面とした場合の数值解析結果と可視化画像 を Fig. 13 に示す．等密度線間隔，可視化の瞬間は Fig. 12 と同一である. 数值解析結果と可視化画像は, 反応生 成気体（C.C.）の形状を除き，おおむね一致した。

C.C. 形状について, 実験結果と数值解析結果とが異 なった原因として，ペレット上の爆轟開始位置の相違が 挙げられる.AUTODYN-2D の仕様のため, Fig. 13 での 爆轟開始位置は, ペレット側面全体である。しかし, 実 験での爆轟開始点は, 当然のことながら光ファイバとの 接触点である (Fig. 7 (c) の起爆法は光ファイバ法).こ の相違が実験結果と数值解析結果, 特に C.C. 形状の差異 として現れた。数值解析の仮定に従うとペレット側面全 体の同時起爆によってペレット内を伝播する爆轟波は外 周から中心軸方向に向かう。そのため内部の物質が爆縮 され，円筒軸に沿った方向に強い噴流が形成される。一 方, 実験では光ファイバはペレット側面の一部に接着さ れており，この領域から爆轟波が発生する。 また，光 ファイバと正対する側面表面には伝播した爆轟波がぺ レット表面で反射することにより強い膨張波が形成され る.すなわち, 実験時のペレット内部の爆轟波伝播過程 と数值解析仮定の相違が, Fig. 13 の C.C. 形状の不一致 の主要な原因である。

ソフトウエアの仕様によるやむを得ない不整合がある が，AUTODYN-2D による解析は，可視化実験で確認し た爆発初期の初期衝撃波内側の構造を再現し, 底面起爆 と側面起爆間の構造の差異を明瞭に示し, I.S. 及び S.S. と Jetとの干渉様態を明らかにした.

以上の結果を総合すると，微小な不規則形状爆薬に 


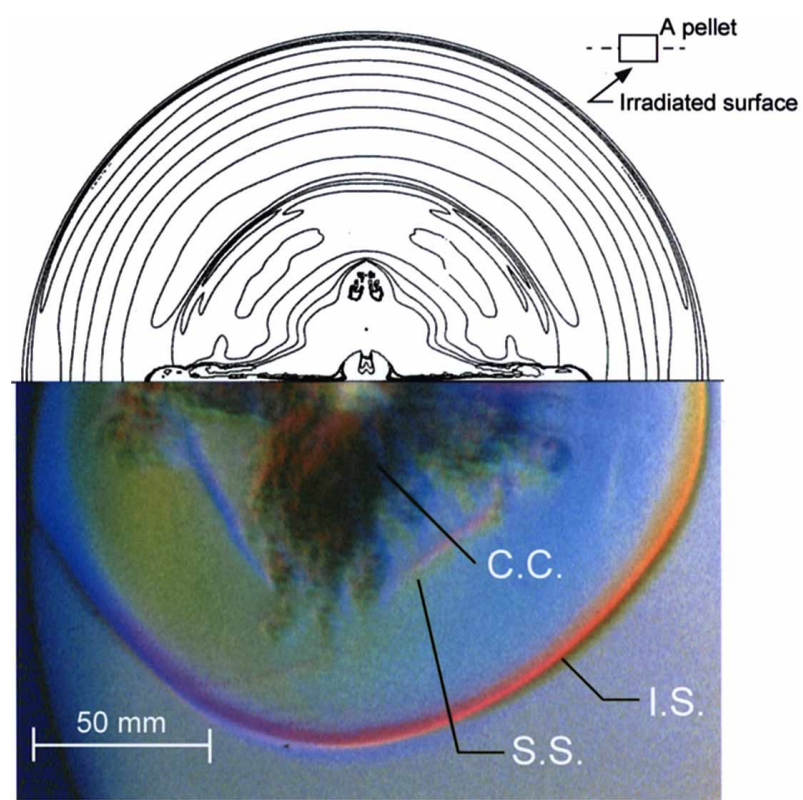

Fig. 13 Numerical results of side-surface ignition at $180 \mu$ s after ignition, I.S.: Incident shock waves, S.S.: Secondary shock waves, C.C.: Combustion Cloud.

よって生じる衝撃波は反応生成気体噴流等の干渉を受け ず，局所的な歪みを生じることはない。逆に，有意な大 きさと軸対称形状（球は除く）を有する爆薬によって生 じる衝撃波の初期形状は，爆薬形状に依存する指向性を 持つ反応生成気体噴流の干渉を受けるため，球状とはな らない.しかし，生じた歪みは伝播の途上で消失し，衝 撃波は球状となる。

\section{5. 結 論}

以上，得られた結果を要約すれば：

（1）アジ化銀ペレットをレーザ起爆した際に発生する衝 撃波について方向指標型カラーシュリーレン法を用 いて可視化計測し，その結果を数值シミュレーショ ンと比較することで衝撃波の初期形状に対する起爆 法及び爆薬形状の影響を明確にした，

(2) 微小で不規則な形状をした爆薬を起爆した際には, 爆発初期においても球状衝撃波が発生する。ただ, 衝撃波はすぐに減衰する,

（3）アジ化銀ペレットのレーザ起爆で発生する衝撃波は 伝播距離が $120 \mathrm{~mm}$ 程度までは起爆法の影響を受け るが，それ以遠では影響は小さくなり，球状衝撃波 と見なしてよい,

（4）アジ化銀ペレットの円筒軸が可視化面に垂直になる よう設置しレーザ光を底面に直接照射することで,
初期衝撃波が受ける歪みが被写界深度方向に集中し, その結果, 歪みが可視化されず, 得られる画像は伝 播距離 $120 \mathrm{~mm}$ 以内でも見かけ上球形となる,

（5）大規模爆発の縮尺実験用衝撃波発生源としてアジ化 銀ペレット（薬量 $10 \mathrm{mg}$ ）を利用する際には，爆心 から距離 $120 \mathrm{~mm}$ 以遠に測定領域を配置すべきであ る.

\section{謝辞}

本研究で用いたペレットは中国化薬 (株)の永易伸生氏 の提供による。また，研究に際しては同氏の助言と協力 を得た。ここに付記し，謝意を表する。また，本研究の 一部は文部省科学研究費 COE 形成プログラム COE003 の助成による.

\section{参考文献}

1 ) Takayama, K.: Application of Underwater Shock Wave Focusing to the Development of Extracorporeal Shock Wave Lithotripsy, Jpn. J. Appl. Phys., Vol. 32 (1993) pp. 2192-2198.

2 ) 谷口宏充, 斉藤務, 木下利博, 高山和喜, 藤井直之 : 火山爆 風の数值シミュレーション，火山, Vol. 39 (1994) pp. 257266 .

3 ) 水書稔治, ハロルド・クライネ, 高山和喜 : アジ化銀ペレッ 卜起爆に用するパルス $\mathrm{Nd}$ ：YAG レーザのしきい值に関する 研究, 火薬学会誌, Vol. 63, No. 2 (2002) pp. 58-64.

4) Cords, P.: A High Resolution, High Sensitivity Color Schlieren Method, S.P.I.E. Journal, Vol. 6 (1968) pp. 85-88.

5 ) Kleine, H., Gronig, H.: Color schlieren methods in shock wave research, Shock Waves, Vol. 1 (1991) pp. 51-63.

6 ）武石賢一郎, 松浦正昭, ハラルド・クライネ, 宮城勢治：新 しいカラーシュリーレン法の衝撃波風洞への適用について, 日本航空宇宙学会誌, Vol. 44, No. 509 (1996) pp. 15-20.

7 ）宮城勢治, Kleine, H. : 色分解カラーシュリーレン法による 高速流体現象のカラー可視化, 平成 5 年衝撃波シンポジウム 講演論文集 (1993) pp. 441-444.

8 ) Miyashiro, S.: Short duration spark source for color schlieren methods, SPIE, Vol. 1801 High-speed photograhy and photonics (1992) pp. 248-257.

9 ) 浅沼強編：流れの可視化ハンドブック, 朝倉書店, 東京 (1977) pp. 331-337.

10) Robinson, N., Hayhurst, C., Fairlie, G.,: Int. J. of Computer Applications in Technology, Vol. 316 (1994) pp. 3-6.

11）羽場政明, 松村知治, 中山良男, 吉田正典: 模擬地下式火薬 庫の爆発影響評価（第 2 報），火薬学会誌，Vol. 61 (2000) pp. 184-191.

12）火薬学会編：エネルギー物質ハンドブック, 共立出版, 東京 (1999) pp. 159-170. 